\title{
Creatine supplementation and oxidative stress in rat liver
}

\author{
Michel B Araújo ${ }^{1 *}$, Leandro P Moura ${ }^{1}$, Roberto C Vieira Junior ${ }^{2}$, Marcelo C Junior ${ }^{1}$, Rodrigo A Dalia ${ }^{1}$, \\ Amanda C Sponton', Carla Ribeiro ${ }^{1}$ and Maria Alice R Mello'
}

\begin{abstract}
Background: The objective of this study was to determine the effects of creatine supplementation on liver biomarkers of oxidative stress in exercise-trained rats.

Methods: Forty 90-day-old adult male Wistar rats were assigned to four groups for the eight-week experiment. Control group (C) rats received a balanced control diet; creatine control group (CCr) rats received a balanced diet supplemented with $2 \%$ creatine; trained group $(\mathrm{T})$ rats received a balanced diet and intense exercise training equivalent to the maximal lactate steady state phase; and supplemented-trained (TCr) rats were given a balanced diet supplemented with $2 \%$ creatine and subjected to intense exercise training equivalent to the maximal lactate steady state phase. At the end of the experimental period, concentrations of creatine, hydrogen peroxide $\left(\mathrm{H}_{2} \mathrm{O}_{2}\right)$ and thiobarbituric acid reactive substances (TBARS) were measured as well as the enzyme activity of superoxide dismutase (SOD), glutathione peroxidase (GSH-GPx) and catalase (CAT). Liver tissue levels of reduced glutathione (GSH), oxidized glutathione (GSSG) and the GSH/GSSG ratio were also determined.
\end{abstract}

Results: Hepatic creatine levels were highest in the $\mathrm{CCr}$ and $\mathrm{TCr}$ groups with increased concentration of $\mathrm{H}_{2} \mathrm{O}_{2}$ observed in the T and TCr animal groups. SOD activity was decreased in the TCr group. GSH-GPx activity was increased in the T and TCr groups while CAT was elevated in the CCr and TCr groups. GSH, GGS and the GSH/GSSG ratio did not differ between all animal subsets.

Conclusions: Our results demonstrate that creatine supplementation acts in an additive manner to physical training to raise antioxidant enzymes in rat liver. However, because markers of liver oxidative stress were unchanged, this finding may also indicate that training-induced oxidative stress cannot be ameliorated by creatine supplementation.

Keywords: Creatine supplementation, Oxidative stress, Enzymes, Treadmill exercise

\section{Background}

Physical activity modifies the balance between oxidative stress and antioxidant defense mechanisms. For both athletes and fitness enthusiasts, the combination of regular physical activity and antioxidant supplementation may have important restorative effects on the body's oxidationreduction or redox balance.

Dietary supplementation with creatine $(\mathrm{CrS})$ is popular in the sports and fitness industry, wherein $\mathrm{CrS}$ is believed to aid in the maintenance of high-energy phosphate reserves during exercise. While certain mechanisms

\footnotetext{
* Correspondence: mbujo@ig.com.br

'Laboratory of Nutrition, Metabolism and Exercise, Department of Physical Education, Universidade Estadual Paulista (UNESP), 24a avenue $n^{\circ} 1515$,

P.O. Box 199, Bela Vista, Rio Claro, São Paulo, Brazil

Full list of author information is available at the end of the article
}

of action involved in improved physical exercise performance with $\mathrm{CrS}$ have been established [1,2], recent research efforts have focused on other CrS benefits, specifically, the use of $\mathrm{CrS}$ in reducing the cellular oxidative stress associated with strenuous long-term exercise [3-5]. Creatine is an end-product of the metabolism of amino acids glycine and arginine, producing guanidinoacetate and participating in the urea cycle. Arginine also acts as a substrate in the nitric oxide synthase pathway and can stimulate the production of nitric oxide free radicals that modulate skeletal muscle and liver metabolism, contractility and glucose uptake [6-8].

Certain amino acids such as histidine, methionine and cysteine are particularly susceptible to oxidation by free radicals [9]. Sulfhydryl cysteine groups are known modulators 
of the redox state across many protein functions that also appear to protect protein sulfhydryl groups and to improve liver function [10].

The antioxidant effects of creatine may derive from different mechanisms of action such as the indirect mechanisms involved in cell membrane stabilization and improved cellular energy capacity [11] and from its direct antioxidant properties [5]. Recently, creatine's potential to act directly to remove reactive oxygen species was investigated [12]. Lawler et al. [5] concluded that creatine has a significant role as a primary antioxidant. Using in vitro techniques, these authors found a dose-response relationship between creatine concentration and the ability to remove superoxide anions $\left(\mathrm{O}_{2} \bullet-\right)$ and peroxynitrite $(\mathrm{OONO})$. As creatine has not shown significant antioxidant activity against hydrogen peroxide $\left(\mathrm{H}_{2} \mathrm{O}_{2}\right)$, these findings also demonstrate creatine's selective antioxidant capacity.

Sestili et al. [4] postulated a direct antioxidant role for creatine in cells exposed to various oxidative agents. These authors demonstrated that creatine in doses similar to those found in plasma after supplementation exerts cytoprotective antioxidant activity in three different cell lines against three different oxidative agents: $\mathrm{H}_{2} \mathrm{O}_{2}, \mathrm{OONO}^{-}$ and $\mathrm{t}$-butyl hydroperoxide (tB-OOH), an organic peroxide widely used in a variety of oxidation processes. Furthermore, cytoprotection was observed independent of the anti-oxidative state of the cell, as evaluated by the antioxidant enzymes catalase and glutathione peroxidase, which suggests a direct interaction between creatine and oxidizing agents and/or free radicals.

In humans, creatine synthesis appears to occur mainly in the liver [13], an organ that requires vast amounts of generated energy to perform its various functions. The high metabolic rate of the liver $(200 \mathrm{kcal} / \mathrm{kg}$ of tissue per day) is directly associated with the high flow of electrons in the mitochondrial respiratory chain [14]. However, some of these electrons are diverted to produce reactive oxygen species (ROS). Several authors have demonstrated that the liver undergoes increased oxidative stress following exercise $[14,15]$.

Thus, we sought to investigate the effects of $\mathrm{CrS}$ on oxidative balance, injury and liver antioxidant defense mechanisms during exercise in a laboratory model. The aims of this study were to: 1 ) determine whether creatine supplementation increased liver creatine stores and 2) determine whether creatine supplementation improved markers of liver oxidative stress following exercise training.

\section{Methods}

\section{Animals and treatment}

Forty 90-day-old male Wistar rats were given free access to water and food. The animals were housed in collective polyethylene cages measuring $37.0 \times 31.0 \times 16.0 \mathrm{~cm}$ with 5 animals per cage, all under controlled conditions of temperature $\left(22^{\circ} \mathrm{C}\right)$ and light/dark cycle $(12 \mathrm{~h} / 12 \mathrm{~h})$. The experiment was submitted to and approved by the Animal Experimentation Ethics Committee at the University of Taubaté - UNITAU, São Paulo State, Brazil (register CEEA / UNITAU n ${ }^{\circ}$ 018/08).

Exercise training was performed and creatine supplementation given over eight weeks with animals allocated into four groups of ten animals in each group: control group $(\mathrm{C})$, sedentary rats that received a balanced control diet; creatine control group (CCr), sedentary rats that received a balanced diet supplemented with $2 \%$ creatine; trained group $(\mathrm{T})$, rats that were subjected to a training protocol and received a balanced diet; and supplemented trained group ( $\mathrm{TCr}$ ), rats that were subjected to a training protocol and received a balanced diet supplemented with $2 \%$ creatine.

\section{Diet}

The animals in the creatine-supplemented groups $(\mathrm{CCr}$ and $\mathrm{TCr}$ ) received the balanced, isocaloric AIN-93 M diet [16] supplemented with $13 \%$ or $2 \%$ monohydrated creatine (All Chemistry, São Paulo, SP, Brazil) [17].

According to Hutman et al. [18] and Vandenbergue et al. [19] creatine supplementation must be provided in two phases, which aims to promote an overload state of this substrate. These phases were designated as a first peak phase and a subsequent maintenance phase. During the peak phase, rats received the $13 \%$ creatine diets for seven days followed by a maintenance phase for the remaining days of the experiment during which rats were fed a $2 \%$ creatine diet. We used the dosage of creatine based on dose for human but there was an adjustment for employment with the animals. The addition of $2 \%$ in diet creatine during the maintenance phase equals 20 g.kg-1 peak in the phase of $13 \%$ were used equivalent to 130 g.kg-1. Still, according to Altman and Dittmer [20], sets the speed rat metabolism is 5 times greater than the human being for this reason these present values of creatine supplementation. Thus, animals that received creatine-supplemented feed were supplemented seven days a week for eight weeks of the experiment.

The animals from groups $\mathrm{C}$ and $\mathrm{T}$ received the balanced isocaloric diet AIN-93 M [16] without addition of creatine. The detailed diet composition is provided in Table 1.

\section{Training protocol}

To determine the Maximum Lactate Steady State (MLSS), series of exercises was performed, rats bearing rectangular loads ran for 25 minutes on a treadmill at different fixed speeds for each series and a 48-hour interval between series. Blood sample was obtained every five minutes for lactate measurement and were taken from a small incision at the end of the tail that was made prior to the beginning 
Table 1 Diets compositions

\begin{tabular}{cccc}
\hline Components & $\begin{array}{c}\text { AIN - 93M* } \\
\text { (g_kg-1) }\end{array}$ & $\begin{array}{c}\text { Addition } \\
\text { of } \mathbf{2 \%} \\
\text { creatine** } \\
\text { (g_kg-1) }\end{array}$ & $\begin{array}{c}\text { Addition } \\
\text { of 13\% } \\
\text { creatine*** } \\
\text { (g_kg-1) }\end{array}$ \\
\hline Creatine & 0.0 & 20.0 & 130.0 \\
Cornstarch & 465.7 & 444.7 & 335.7 \\
Casein (85\% protein) & 140.0 & 140.0 & 140.0 \\
Dextrin & 155.0 & 155.0 & 155.0 \\
Sucrose & 100.0 & 100 & 100 \\
Soybean oil & 40.0 & 40.0 & 40.0 \\
Fiber & 50.0 & 50.0 & 50.0 \\
Mineral mix & 35.0 & 35.0 & 35.0 \\
Vitamin min & 10.0 & 10.0 & 10.0 \\
L-cystine & 1.8 & 1.8 & 1.8 \\
Choline bitartrate & 2.5 & 2.5 & 2.5 \\
Kcal/Kg & $3.802,77$ & $3.802,77$ & $3.802,77$ \\
\hline
\end{tabular}

*American Institute of Nutrition (AIN-93M) [16].

**Creatine maintenance diet according to Demenice et al. [17].

***Creatine peak diet addapted from Demenice et al. [17] and according to

Hultman et al. [18] and Vandenbergue et al. [19].

of exercise and was sufficient for all specimen collections. The blood lactate concentration representative of the MLSS was considered that obtained from the highest speed where there was no variation in blood lactate between 10 and $25 \mathrm{~min}$ of exercise was no greater than 1.0 $\mathrm{mmol} / \mathrm{L}[10,20]$. The blood lactate concentration was determined by an enzymatic method [21].

The average MLSS for all rats was $26 \mathrm{~m} / \mathrm{min}$. Thus, all rats were trained at this intensity for 40 minutes/day, five days/week for the duration of the experiment.

\section{Biochemical analysis}

Animals were sacrificed after anesthesia with $\mathrm{CO}_{2}$ at the conclusion of the experiment in the fed state and 48 hours after the last "in vivo" evaluation. Blood, liver and gastrocnemius muscle were removed for creatine measurement as described by Clark [22]. As biomarkers of oxidative stress, $\mathrm{H}_{2} \mathrm{O}_{2}$ was determined as hydrogen peroxide (Amplex UltraRed Reagent ${ }^{\circ}$ kit, Life Technologies Corporation, Grand Island, New York, USA) and thiobarbituric acid reactive substances (TBARS) [23] were also evaluated.

As indicators of the antioxidant system, enzymatic activity was analyzed for superoxide dismutase (SOD) (Cayman Chemical commercial kit, Ann Arbor, Michigan, USA), glutathione peroxidase (GSH-GPx) (Cayman Chemical commercial kit, Ann Arbor, Michigan, USA) and catalase (CAT) [24]. Glutathione, both reduced (GSH) and oxidized (GSSG), were analyzed according to the method of Hissin and Hilf [25].

\section{Statistical analysis}

The normality of the data was confirmed by the ShapiroWilks test. The results are presented as the mean \pm S.E. (standard error). Comparisons between groups were made through an analysis of variance (ANOVA Two-Way) and the Tukey HSD post-hoc test when necessary. A predetermined 5\% significance level was used for all the analyses. The statistical program used was the STATISTICA', version 7.0.

\section{Results}

\section{Creatine concentration in the liver}

Animals supplemented with creatine showed significant increase in hepatic creatine concentration when were compared to animals that received no supplementation (Figure 1).

\section{Concentration of hydrogen peroxide $\left(\mathrm{H}_{2} \mathrm{O}_{2}\right)$ and} thiobarbituric acid reactive substances (TBARS) in the liver

Liver $\mathrm{H}_{2} \mathrm{O}_{2}$ levels obtained at the end of the experiment were significantly increased in the exercise-trained groups $\mathrm{T}$ and $\mathrm{TCr}$ in relation to control groups $\mathrm{C}$ and $\mathrm{CCr}$ (Figure 2A).

The values for hepatic TBARS at the end of experiment did not differ between groups (Figure 2B).

\section{Activity of superoxide dismutase (SOD), glutathione} peroxidase (GSH-GPx) and catalase (CAT) in the liver Hepatic SOD activity at the end of the experiment showed decreased activity in rats from the TCr group when they were compared with rats from $\mathrm{CCr}$ group (Figure 3A). Hepatic GSH-GPx activity at the end of the experiment was elevated in groups $\mathrm{T}$ and $\mathrm{TCr}$ compared

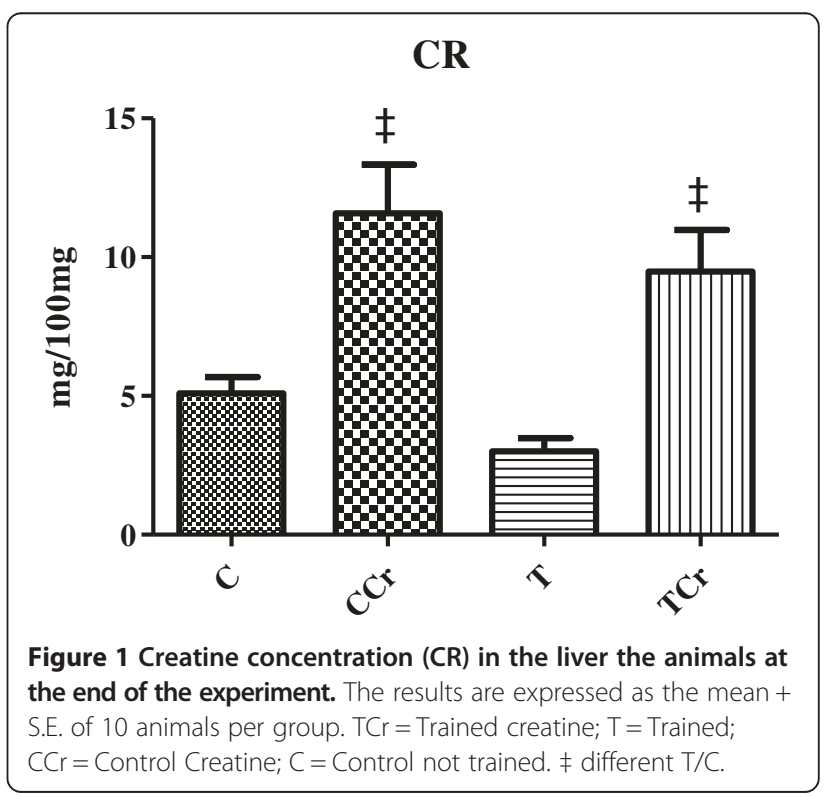



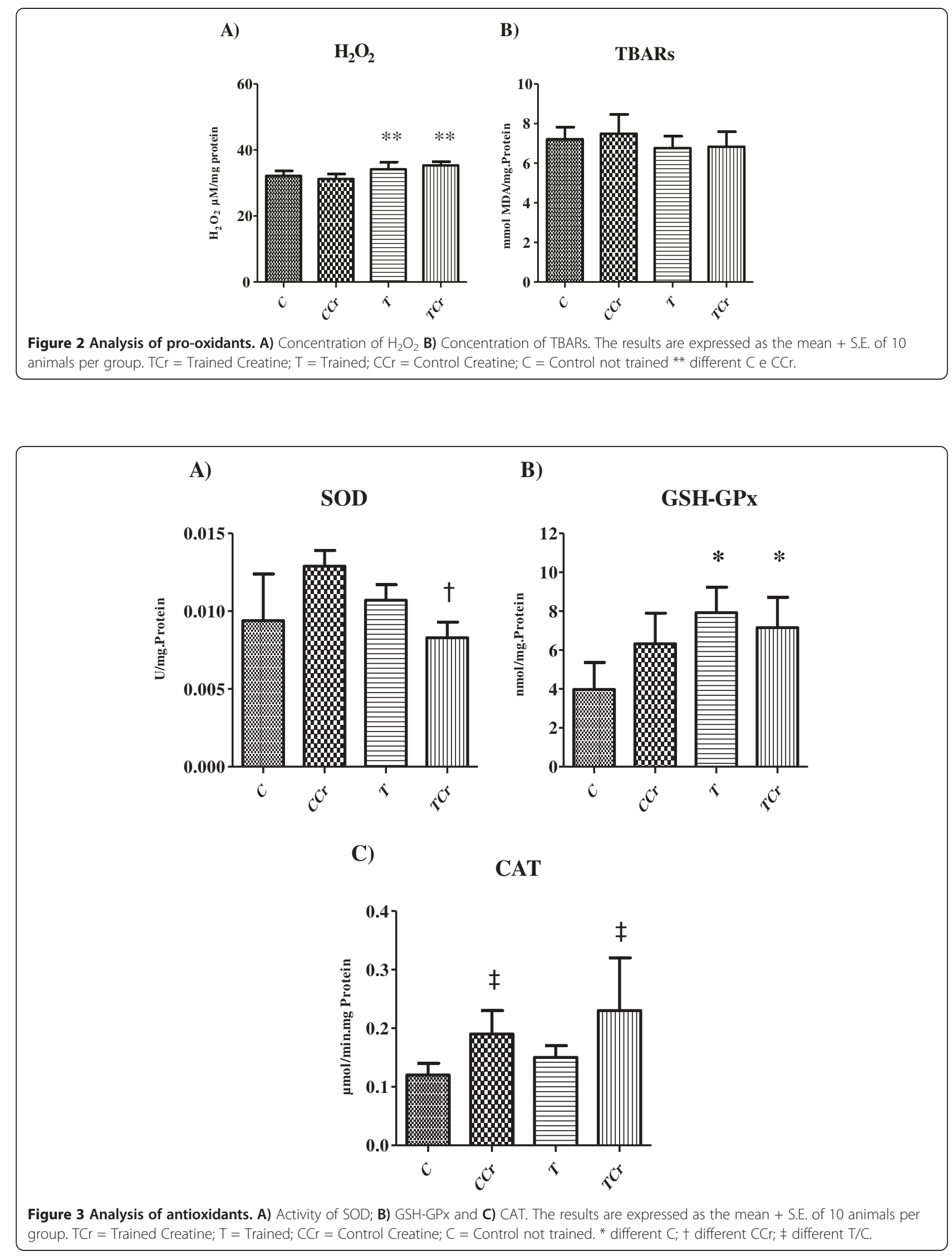
with group $\mathrm{C}$ rats (Figure $3 \mathrm{~B}$ ). Values obtained for hepatic CAT activity at the end of the experiment showed no differences between groups (Figure 3C). There was an increase in the activity of CAT in rats from the $\mathrm{CCr}$ and $\mathrm{TCr}$ groups in relation to those in control groups $\mathrm{C}$ and $\mathrm{T}$ (Figure $3 \mathrm{C}$ ).

\section{Concentration of reduced glutathione (GSH), oxidized glutathione (GSSG) and ratio between reduced glutathione and oxidized glutathione (GSH/GSSG) in liver}

Rat liver values for GSH, GSSG and GSH/GSSG ratio at the end of the experiment showed no differences between groups (Figure 4).

\section{Discussion}

In recent years the use of creatine supplementation $(\mathrm{CrS})$ whith antioxidant function has increased. Several studies have confirmed these effects and pointed to creatine as a new alternative in the prevention of oxidative stress in which creatine appears to play a crucial role in reducing the toxic effects of endogenous production of reactive oxygen species (ROS) [5,26-28].
The literature indicates that $2 \% \mathrm{CrS}$ in animal feed is able to trigger a significant increase in phosphocreatine (PCr) and creatine levels in rat tissues [29,30]. Using this amount of creatine, McMillen et al. [30] observed a significant increase in the total creatine content of rat gastrocnemius muscle in two weeks of supplementation. In the present study, significant increase in the hepatic creatine concentrations were demonstrated in $\mathrm{CCr}$ and $\mathrm{TCr}$ rats compared to the non-supplemented control groups, which supports prior findings in the literature [30,31].

After confirming that dietary supplementation increased creatine concentration in rat liver, this study aimed to evaluate the possible antioxidant effects of $\mathrm{CrS}$ in vivo. The results demonstrate that creatine exerts indirect antioxidant activity in rat liver, i.e., creatine increased the activity of antioxidant enzymes GSH-GPx and CAT. However, $\mathrm{CrS}$ was not effective in normalizing the increased concentrations of $\mathrm{H}_{2} \mathrm{O}_{2}$ triggered by exercise. In addition, no significant differences were observed in the concentration of TBARS between groups.

$\mathrm{H}_{2} \mathrm{O}_{2}$ plays an important role in homeostasis. It participates in cellular induction of gene expression, among which are those genes responsible for antioxidant enzyme synthesis [32-34]. In the present study, we demonstrated
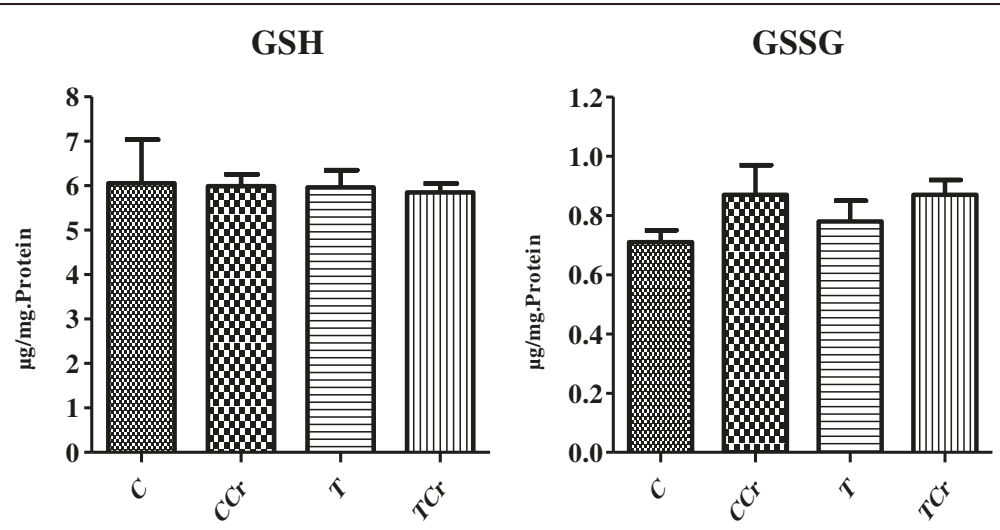

GSH/GSSG

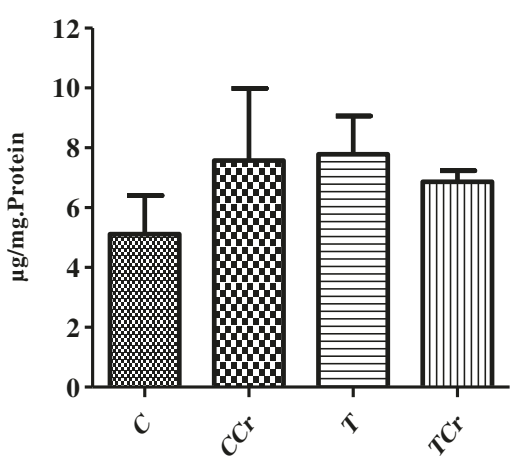

Figure 4 Concentration of reduced glutathione, oxidized glutathione and ratio reduced glutathione/oxidized glutathione in the liver the animals at the end of the experiment. The results are expressed as the mean + S.E. of 10 animals per group. $\mathrm{TCr}=\mathrm{Trained} \mathrm{Creatine} ; \mathrm{T}=$ Trained; $\mathrm{CCr}=$ Control Creatine; $\mathrm{C}=$ Control not trained. 
that exercise-trained rats ( $\mathrm{T}$ and $\mathrm{TCr}$ ) had higher concentrations of $\mathrm{H}_{2} \mathrm{O}_{2}$ than sedentary rats $(\mathrm{C}$ and $\mathrm{CCr})$. These data reinforce the observations of several authors that indicate that creatine appears to exert selective antioxidant effects [26,27]. Lawler et al. [5] have shown that creatine was able to remove $\mathrm{O}_{2} \bullet$ - and $\mathrm{OONO}^{-}$but had no effect on $\mathrm{H}_{2} \mathrm{O}_{2}$. Thus, the direct antioxidant actions of creatine appear to be limited to certain types of free radicals or reactive oxygen species. Sestili et al. [4] have found that creatine was not able to significantly counteract the concentrations of $\mathrm{H}_{2} \mathrm{O}_{2}$ and the compound $\mathrm{tB}-\mathrm{OOH}$ that is derived from $\bullet \mathrm{OH}$ and $\mathrm{RO} \cdot$ radicals.

With regard to levels of TBARS, our results are consistent with previous findings [35] that showed no change in hepatic TBARS levels in treadmill exercisetrained rats. Taken in aggregate, these results for prooxidant markers underscore the findings of Sjodin et al. [36] and Souza et al. [37], that is, predominantly aerobic exercise causes increased oxygen flow in the mitochondria and approximately five percent of this oxygen is not completely reduced, thereby forming ROS.

As $\mathrm{H}_{2} \mathrm{O}_{2}$ levels rise, homeostasis requires increased production of antioxidant enzymes such as SOD, GSHGPx and CAT to maintain the balance between oxidant production and the antioxidant system $[8,38,39]$. Our study results for SOD demonstrate decreased enzymatic activity in trained animals ( $\mathrm{T}$ and TCR) when they were compared to group $\mathrm{C}$ rats. SOD is important in the metabolism of $\mathrm{O} 2$ - that results in the formation of $\mathrm{H}_{2} \mathrm{O}_{2}$ $[34,40,41]$. Thus, while SOD is an important combatant against oxidative stress, it also accelerates the formation of hydrogen peroxide, as occurs during physical exercise. In this situation, it has been suggested that reduced SOD activity is mainly explained by the inhibitory effect of increased $\mathrm{H}_{2} \mathrm{O}_{2}$ production [42].

In this study, a hypothesis may explain the decrease in SOD activity in response to $\mathrm{CrS}$. Creatine may exert a sparing effect, i.e., creatine may act to neutralize ROS, resulting in down-regulation of the antioxidant system and specifically, the action of SOD. This hypothesis is based on research of antioxidant supplementation use that demonstrated inhibition of SOD, GSH-GPx and CAT activity $[43,44]$. However, a notable finding from these studies was that unlike SOD, the activity of GSHGPx and CAT were increased in trained animals and CrS. Both GSH-GPx and CAT enzymes are present in most aerobic organisms and are responsible for conversion of intracellular $\mathrm{H}_{2} \mathrm{O}_{2}$ to water and oxygen $[34,40]$.

Our study demonstrated increase in GSH-GPx levels in exercised-trained rat groups $\mathrm{T}$ and $\mathrm{TCr}$ compared to control group animals. This finding may be explained by the fact that regular physical training activates transcription factors such as NF-kB and Nrf2, which are responsible for triggering various genes, including mitochondrial GSH-
GPx $[45,46]$. Moreover, the effect of training on the activity and expression of CAT is inconsistent and controversial [47]. However, increased activity of this enzyme has been observed in rat liver [48], mice liver [49] and trained rat heart [50].

The most striking finding we encountered was the increased CAT activity that occurred only in animals given $\mathrm{CrS}$. This result appears to support an additive role for creatine on the actions of antioxidant enzymes. Physical training, as demonstrated by Halliwell and Gutteridge [51], activates transcription factors such as AMPK, which activate CAT mRNA, thereby stimulating protein synthesis and possibly increasing CAT activity. The ability of $\mathrm{CrS}$ to also exert this effect remains controversial. According to Sestile et al. [4], creatine has neutralizing effects on ROS production that do not interfere on the action of antioxidant enzymes. However, the increase in CAT activity observed in this study is attributed to the formation of $\mathrm{H}_{2} \mathrm{O}_{2}$ by SOD. According to Halliwel and Gutteridge [51], the chemical interaction of $\mathrm{H}_{2} \mathrm{O}_{2}$ at the catalase active site involves the transfer of a hydrogen ion between the two oxygen atoms, causing a heterolytic cleavage with water and oxygen end products. The findings in our study of increased $\mathrm{H}_{2} \mathrm{O}_{2}$ levels in trained and supplemented animals combined with the neutralizing action of creatine on this ROS may explain the reduced oxidative damage seen with increased CAT activity.

In contrast, the amounts of GSH and GSSG as well as the ratio between GSH/GSSG did not differ between the study groups. GSH has a central role in the biotransformation and elimination of xenobiotics, and protects cells against oxidative stress [52]. To maintain the protective activity of glutathione as expressed by the reduction of oxidizing species and consequent oxidation of GSH to GSSG, GSH must be regenerated through the catalytic cycle [52].

In summary, our study results demonstrate that creatine supplementation acts in an additive manner to physical training to increase antioxidant enzymes in rat liver. More studies are needed to expand our knowledge of the antioxidant effects of creatine and to investigate creatine's little-known effects on other body tissues.

\section{Competing interests}

The authors declare that they have no competing interests.

\section{Authors' contributions}

MBA (corresponding author) was responsible for the study design, execution of biochemical analysis, statistical analysis and writing of the manuscript.

LPM held the writing of the manuscript. RCVJ, MCJ, RAD, ACS, CR and MARM participated in the realization of biochemical analysis. All authors read and approved the final manuscript.

\section{Acknowledgements}

The authors are grateful for the technical support of Clarice Y. Sibuya and José Roberto R. da Silva who contributed greatly to this Project. 


\section{Funding}

This study was supported by "The State of São Paulo Foundation for Research Support" (FAPESP - Proc. 2009/52063-0).

\section{Author details}

'Laboratory of Nutrition, Metabolism and Exercise, Department of Physical Education, Universidade Estadual Paulista (UNESP), 24a avenue $n^{\circ} 1515$, P.O. Box 199, Bela Vista, Rio Claro, São Paulo, Brazil. ²Post-Graduation Program - Graduation in Bioscience of Faculty of Nutrition from Federal University of Mato Grosso, UFMT, Cuiabá, Mato Grosso, Brazil.

Received: 19 October 2012 Accepted: 5 December 2013 Published: 10 December 2013

\section{References}

1. Gama MS: Efeitos da creatina sobre desempenho aeróbio: uma revisão sistemática. Revista Brasileira de Nutrição Esportiva 2011, 5:182-190.

2. Pereira Júnior M, Moraes AJP, Ornellas FH, Gonçalves MA, Liberalli R, Navarro F: Eficiência da suplementação de creatina no desempenho físico humano. Revista Brasileira Prescrição e Fisiologia do Exercício 2012, 6:90-97.

3. Cruzat VF, Rogero MM, Borges MC, Tirapegui J: Aspectos atuais sobre estresse oxidativo, exercícios físicos e suplementação. Rev Bras Med Esporte 2007, 13:336-342.

4. Sestili P, Martinelli C, Bravi G, Piccoli G, Curci R: Creatine supplementation affords cytoprotection in oxidatively injured cultured mammalian cells via direct antioxidant activity. Free Radic Biol Med 2006, 40:837-849.

5. Lawler JM, Barnes WS, Wu G, Song W, Demaree S: Direct antioxidant properties of creatine. Biochem Biophys Res Commun 2009, 290:47-52.

6. Reid MB: Nitric oxide, reactive oxygen species, and skeletal muscle contraction. Med Sci Sports Exer 2001, 33:371-376.

7. Freire TO, Gualano B, Leme MD, Polacow VO, Lancha AH Jr: Efeitos da Suplementação de Creatina na Captação de Glicose em Ratos Submetidos ao Exercício Físico. Rev Bras Med Esporte 2008, 14:431-435.

8. Araújo MB, Mello MAR: Exercício, estresse oxidativo e suplementação com creatina. Revista Brasileira de Nutrição Esportiva 2009, 3:264-272.

9. Grune T, Reinheckel T, Davies KJA: Degradation of oxidized proteins in mammalian cells. FASEB J 1997, 11:526-534.

10. Araújo MB, Moura LP, Ribeiro C, Dalia RA, Voltarelli FA, Mello MAR: Oxidative stress in the liver of exercised rats supplemented with creatine. Int J Nutr Metab 2011, 3:58-64.

11. Wyss M, Schulze A: Health implications of creatine: can oral creatine supplementation protect against neurological and atherosclerotic disease? Neuroscience 2002, 112:243-260.

12. Matthews RT, Yang L, Jenkins BG, Ferrante RJ, Rosen BR: Neuroprotective effects of creatine and cyclocreatine in animal models of Huntington's disease. J Neurosci 1998, 18:156-163.

13. Williams MH, Kreider R, Branch JD: Creatina. São Paulo: Ed Manole; 2000.

14. Ogonovszky H, Sasvári M, Dosek A, Berkes I, Kaneko T, Tahara S: The effects of moderate, strenuous, and overtraining on oxidative stress markers and DNA repair in rat liver. Can J Appl Physiol 2005, 30:186-195.

15. Navarro-Arevalo A, Sanchez-del-Pino MJ: Age and exercise related changes in lipid peroxidation and superoxide dismutase activity in liver and soleus muscle tissues of rats. Mech Ageing Dev 1998, 104:91-102.

16. OReeves PG, Nielsen FH, Fahey GC Jr: AIN-93 purified diets for laboratory rodents: final report of the American Institute of Nutrition ad hoc writing committee on the reformulation of the AIN-76A rodent diet. J Nutr 1993, 123:1939-195.

17. Deminice R, Portari GV, Vannucchi H, Jordao AA: Effects of creatine supplementation on homocysteine levels and lipid peroxidation in rats. Br J Nutr 2009, 102:110-116.

18. Hultman E, Soderlund K, Timmons J, Cederblad G, Greenhaff P: Muscle creatine loading in man. J Appl Physiol 1996, 81:232-237.

19. Vandenberghe $K$, Goris M, Van Hecke P, Van Leemputte M, Vangerven L, Hespel P: Long-term creatine intake is beneficial to muscle performance during resistance training. J Appl Physiol 1997, 83:2055-2063.

20. Manchado FB, Gobatto CA, Contarteze RVL, Papoti M, Mello MAR: Maximal lactate steady in running rats. J Exer Physiol Online 2005, 8:29-35.

21. Hill $A V$, Long $C N H$, Lupton $H$ : Muscular exercise, lactic acid, and the supply and utilization of oxygen: parts IV-VI. Proc R Soc B 1924, 97:84-138.

22. Clark LC, Thompson HL: The determination of creatine and creatinine in urine. Anal Chem 1949, 21:1218-1221.
23. Mataix J, Quiles JL, Huertas JR, Battino M, Manas M: Tissue specific interactions of exercise, dietary fatty acids, and vitamin $\mathrm{E}$ in lipid peroxidation. Free Radic Biol Med 1998, 24:511-521.

24. Aebi H: Catalase in vitro. Methods Enzymol 1984, 105:121-126.

25. Hissin PJ, Hilf R: A flurometric method for determination of oxidizid and reduced glutathione in tissues. Anal Biochem 1976, 74:214-226.

26. Souza Junior TP, Pereira B: Creatina: auxílio ergogênico com potencial antioxidante? Rev Nutr 2008, 21:349-353.

27. Deminice R, Sicchieri T, Mialich MS, Milani F, Ovidio PP, Jordao AA: Oxidative stress biomarker responses to an acute session of hypertrophy-resistance traditional interval training and circuit training. J Strength Cond Res 2011, 25:798-804.

28. Guimarães-Ferreira L, Hermano CJ, Gerlinger-Rom PF, Vitze KFL, Nachbar RT, Curi R, Nunes MT: Short-term creatine supplementation decreases reactive oxygen species content with no changes in expression and activity of antioxidant enzymes in skeletal muscle. Eur J Appl Physiol 2012, 2012(112):801-1196.

29. Brannon TA, Adams GR, Gonniff CL, Baldwin KM: Effects of creatine loading and training on running performance and biochemical properties of rat skeletal muscle. Med Sci Sports Exerc 1997, 29:489-495.

30. McMillen J, Donovan CM, Messer Jl, Willis WT: Energetic driving forces are maintained in resting rat skeletal muscle after dietary creatine supplementation. J Apply Physiol 2001, 90:62-66.

31. Rawson ES, Clarkson PM: Scientifically debatable: Is creatine worth its weight? Sports Sci Exch 2003, 16:1-6.

32. Mandal BA, Chakraborty CD: Oxidant, antioxidant and physical exercise. Mol Cell Biochem 2003, 253:307-312.

33. Ji LL, Gomez-Cabrera MC, Vina J: Exercise and hormesis: activation of cellular antioxidant signaling pathway. Ann N Y Acad Sci 2006, 1067:425-435.

34. Ferreira F, Ferreira R, Duarte JÁ: Stress oxidativo e dano oxidativo muscular esquelético: influência do exercício agudo inabitual e do treino físico. Revista Portuquesa de Ciência do Desporto 2007, 7:257-275.

35. Araújo MB, Voltarelli FA, Manchado-Gobatto FB, Moura LP, Mello MAR: Treinamento em diferentes intensidades e biomarcadores de estresse oxidativo e do metabolismo glicídico musculoesquelético de ratos. Revista da Educação Física/UEM 2010, 21:695-707.

36. Sjodin B, Wesling HE, Apple S: Biochemical mechanisms for oxygen free radical formation during exercise. Sports Med 1990, 10:236-254.

37. Souza RA, Santos RM, Osório RA, Cogo JC, Priati Júnior ACG: Influência da suplementação aguda e crônica de creatina sobre as concentrações sanguíneas de glicose e lactato de ratos Wistar. Rev Bras Med Esporte 2006, 12:361-365.

38. Araújo MB, Prada FJA, Mello MAR: Estresse oxidativo no exercício, modelos animais e intensidade do esforço. Motriz 2006, 2006(12):307-312.

39. Fisher-Wellman K, Bloomer RJ: Acute exercise and oxidative stress: a 30 year history. Dyn Med 2009, 8:1-25.

40. Lee J, Koo N, Min DB: Reactive oxygen species, aging, and antioxidative nutraceuticals. Compr Rev Food Sci Food Saf 2004, 3:21-33.

41. Mota MP, Figueiredo P, Duarte JÁ: Teorias biológicas do envelhecimento. Revista Portuguesa de Ciências do Desporto 2004, 4:81-110.

42. Machefer G, Groussard C, Rannou-Bekono F, Zouhal H, Faure H: Extreme Running Competition Decreases Blood Antioxidant Defense Capacity. J Am Coll Nutr 2004, 23:358-364.

43. Asha Devi S, Ravi Kiran T: Regional responses in antioxidant system to exercise training and dietary Vitamin E in aging rat brain. Neurol Aging 2004, 25:501-508.

44. Hamid NAA, Hasrul MA, Ruzanna RJ, Ibrahim IA, Baruah PS: Effect of vitamin $\mathrm{E}\left(\right.$ Tri $\mathrm{E}^{\oplus}$ ) on antioxidant enzymes and DNA damage in rats following eight weeks exercise. Nutr J 2011, 10:37.

45. Tromm CB, Rosa GL, Bom K, Mariano I, Pozzi B: Efeito de diferentes frequências semanais de treinamento sobre parâmetros de estresse oxidativo. Revista Brasileira de Cineantropometria e Desempenho Humano 2011, 14:52-60.

46. Yu Z, Li D, Ling W, Jin T: Role of nuclear factor (erythroid-derived 2)-like 2 in metabolic homeostasis and insulin action: A novel opportunity for diabetes treatment? World J Diabetes 2012, 3:19-28.

47. Pinho RA, Andrades ME, Oliveira MR, Pirola AC, Zago MS, Silveira PC: Imbalance in SOD/CAT activities in rat skeletal muscles submitted to treadmill training exercise. Cell Biol Int 2006, 30:848-853.

48. Silva LA, Ronsanil MM, Souza PS, Severino BJ, Fraga DB: Comparação do treinamento físico de quatro e oito semanas sobre atividade da cadeia 
transportadora de elétrons e marcadores de estresse oxidativo em fígado de camundongos. Rev Bras Med Esporte 2010, 16:126-129.

49. Souza RA, Miranda $H$, Xavier M, Salles BF, Simão R: Influência da suplementação aguda e crônica de creatina sobre marcadores enzimáticos de dano muscular de ratos sedentários e exercitados com natação. Revista Brasileira de Educação Física e Esporte 2010, 24:343-352.

50. Husain K, Somani SM: Interaction of exercise and adenosine receptor agonist and antagonist on rat heart antioxidant defense system. Mol Cell Biochem 2005, 270:209-214.

51. Halliwell B, Gutteridge MC: Free radicals in biology and medicine. Oxford: University Press; 2007.

52. Huber PC, Almeida WP: Glutationa e enzimas relacionadas: papel biológico e importância em processos patológicos. Quim Nova 2008, 31:S1-S4.

doi:10.1186/1550-2783-10-54

Cite this article as: Araújo et al:: Creatine supplementation and oxidative stress in rat liver. Journal of the International Society of Sports Nutrition 2013 10:54

\section{Submit your next manuscript to BioMed Central and take full advantage of:}

- Convenient online submission

- Thorough peer review

- No space constraints or color figure charges

- Immediate publication on acceptance

- Inclusion in PubMed, CAS, Scopus and Google Scholar

- Research which is freely available for redistribution 